Atıf için / For Citation: B. Yıldız, A. Erkişi, "Ab-initio calculations; mechanical and electronic properties of new $\mathrm{M}_{4} \mathrm{As}_{3} \mathrm{Co}$ (M: Al, Ga) compounds", Süleyman Demirel Üniversitesi Fen Edebiyat Fakültesi Fen Dergisi, 16(1), 86-95, 2021.

\title{
Ab-initio Calculations; Mechanical and Electronic Properties of New M4As3 Co (M: Al, Ga) Compounds
}

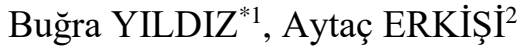 \\ ${ }^{1}$ Hacettepe University, Faculty of Engineering, Department of Physics Engineering, 06800, Ankara, \\ Turkey \\ ${ }^{2}$ Pamukkale University, Faculty of Arts and Sciences, Department of Physics, 20020, Denizli, Turkey \\ *corresponding author e-mail: bugrayildiz@hacettepe.edu.tr
}

(Alinış / Received: 02.02.2021, Kabul / Accepted: 02.03.2021, Yayımlanma / Published: 27.05.2021)

\begin{abstract}
In this study, electronic, magnetic and mechanical properties of $\mathrm{Al}_{4} \mathrm{As}_{3} \mathrm{Co}$ and $\mathrm{Ga}_{4} \mathrm{As}_{3} \mathrm{Co}$ compounds have been investigated in detail. All the calculations have been done by using Vienna Ab initio Simulation Package by using Generalized Gradient Approximation (GGA) within Density Functional Theory (DFT). $\mathrm{M}_{4} \mathrm{As}_{3} \mathrm{Co}$ (M: Al, Ga) compounds have simple cubic structure and they have F-43m space group with 216 space number. In order to find most suitable magnetic order, ferromagnetic and three type of antiferromagnetic orders have been employed. Although all the ground state energies for both of our materials are close to each other, it is understood that, energetically most stable magnetic order is ferromagnetic order. After optimization procedure, electronic band structures with density of states have been plotted. Plots prove that, $\mathrm{Al}_{4} \mathrm{As}_{3} \mathrm{Co}$ compound has semiconductor nature with very little direct band gap $0.044 \mathrm{eV}$ while $\mathrm{Ga}_{4} \mathrm{As}_{3} \mathrm{Co}$ compound has zero indirect band gap. Finally, elastic constants have been calculated and important mechanical properties have been estimated. As result of these estimation, it could be said that our materials are mechanically stable.
\end{abstract}

Key words: Semiconductor, Zero band gap, Density functional theory, Ferromagnet.

\section{Yeni M4Ass Co (M: Al, Ga) Bileşiğinin Ab-initio Hesaplamaları ile Mekanik ve Elektronik Özellikleri}

Özet: $\mathrm{Bu}$ çalışmada, $\mathrm{Al}_{4} \mathrm{As}_{3} \mathrm{Co}$ ve $\mathrm{Ga}_{4} \mathrm{As}_{3} \mathrm{Co}$ bileşiklerinin elektronik, manyetik ve mekanik özellikleri detaylı bir şekilde incelenmiştir. Tüm hesaplamalar Vienna Ab initio Simulation Package kullanılarak Yoğunluk Fonksiyoneli Teorisi (YFT) içinde Genelleştirilmiş Gradyant Yaklaşımı (GGY) kullanılarak yapılmıştır. $\mathrm{M}_{4} \mathrm{As}_{3} \mathrm{Co}(\mathrm{M}$ : Al, Ga) bileşikleri basit kübik yapıya sahip olup 216 uzay numaralı ve F-43m uzay grubuna sahiptir. En uygun manyetik düzeni bulmak için ferromanyetik ve üç tip antiferromanyetik düzen kullanılmıştır. Her iki malzememiz için tüm taban durum enerjileri birbirine yakın olmasına rağmen, enerjisel olarak en kararlı manyetik düzenin ferromanyetik düzen olduğu anlaşılmaktadır. Optimizasyon prosedürünün ardından, durum yoğunluğuna sahip elektronik bant yapısı çizilmiştir. Grafikler, $\mathrm{Ga}_{4} \mathrm{As}_{3} \mathrm{Co}$ bileşiğinin sıfır dolaylı bant aralığına sahip olduğunu kanıtlarken, $\mathrm{Al}_{4} \mathrm{As}_{3} \mathrm{Co}$ bileşiğinin de 0,044 eV'luk çok küçük doğrudan bant aralığı ile yarı iletken doğaya sahip olduğunu kanıtlamaktadır. Son olarak, elastik sabitler hesaplanmış ve önemli mekanik özellikler tahmin edilmiştir. Bu tahminler sonucunda, malzemelerimizin mekanik olarak kararlı olduğu söylenebilir.

Anahtar kelimeler: Yariletken, Sıfır bant aralığı, Yoğunluk fonksiyoneli teorisi, Ferromanyetik. 


\section{Introduction}

Over the recent decades, comprehensive knowledge of mechanical, electronic and optical features of crucial semiconductors such as GaAs, GaP have been obtained in detail [1]. Gallium arsenide has been used in the production of devices such as solar cells, laser diodes and integrated circuits [2]. Some electronic and mechanical properties of GaAs are superior than silicon. Phonon dispersion and electronic band structures of semiconductors like $\mathrm{Ga}_{n} \mathrm{As} \mathrm{s}_{\mathrm{m}} \mathrm{Ti}$ and $\mathrm{Ga}_{n} \mathrm{P}_{\mathrm{m}} \mathrm{Ti}$ have been studied in detail [3]. Furthermore, electronic properties and band structures of semiconductor materials such as $\mathrm{Ga}_{4} \mathrm{As}_{3} \mathrm{Ti}$ and $\mathrm{Ga}_{4} \mathrm{P}_{3} \mathrm{Ti}$ have been investigated [4]. It has been shown that, the existence of intermediate band makes these materials to be decisive photovoltaic compounds [5].

In addition to that, discovery of ferromagnetic semiconductors makes these types of compounds very important for spintronic applications [6-12]. Spintronics [13] refers to the investigation of spin and its associated magnetic moment in solid state devices, in addition to the electronic charge [14]. Spintronics, which are using the spins of electrons as information carriers, have great potential for future technologies, since they low energy consumption and accelerate data processing with high circuit integration density. With semi-conductor and zero-gap band structure, our materials can be good candidate for spintronic applications.

In this study, we have done comprehensive ab-initio analysis to understand mechanical, electronic and magnetic properties of the $\mathrm{M}_{4} \mathrm{As}_{3} \mathrm{Co}(\mathrm{M}: \mathrm{Al}, \mathrm{Ga})$ materials. The materials in this study have been obtained by substituting certain transition metal atoms from the cubic GaAs compound. The spin polarized density of states and electronic band structure [15] have been determined within generalized gradient approximation (GGA) by using density functional theory (DFT). All the calculations have been done in most suitable magnetic order which is ferromagnetic phase. For that reason, the ferromagnetic phase and three different antiferromagnetic phases have been considered. Moreover, to find out mechanical stability of the materials, elastic constants have been calculated and two-dimensional linear compressibility, shear and Young's modulus and Poisson's ratio have been visualized. Adding new semiconductor materials has great significance, since it could be used for potential future applications. Also, for this compound, there is no theoretical or experimental study in the literature.

\section{Computational Details}

All the calculations have been done by using Vienna Ab initio Simulation Package (VASP) [16-17] with projector augmented wave method [18] by using density functional theory (DFT) [19-20]. Perdew Burke Ernzerhof (PBE) functionals have been used within generalized gradient approximation (GGA) for exchange correlation terms in electron-electron interactions [21]. Valance electron configurations for $\mathrm{Al}, \mathrm{Ga}, \mathrm{As}$ and Co are given respectively; $3 s^{2} 3 p^{1}, 4 s^{2} 3 d^{10} 4 p^{1}, 4 s^{2} 3 d^{10} 4 p^{3}, 4 s^{2} 3 d^{7}$.

In order to achieve optimized structural parameters, $12 \times 12 \times 12$ Monkhorst-Pack scheme [22] k-points samplings have been used. Also, cut-off energy has been chosen as 900 $\mathrm{eV}$.

Kohn-Sham equations have been determined iteratively and numerically and iteration continued until all the forces on each atom become less than $10^{-8} \mathrm{eV} / \AA$. The structural visualizations have been done by using VESTA [23]. Then, in order to choose suitable 
magnetic order, $2 \times 2 \times 2$ super-cell has been used and volume of cells and total energies have been calculated. And then, structural parameters, elastic constants, electronic band structures and density of states have been investigated for the most proper magnetic order.

\section{Results}

$\mathrm{M}_{4} \mathrm{As}_{3} \mathrm{Co}(\mathrm{M}$ : Al, Ga) compounds have simple cubic structure with F-43m space group and 216 space number. The three-dimensional primitive cell of $\mathrm{M}_{4} \mathrm{As}_{3} \mathrm{Co}(\mathrm{M}: \mathrm{Al}, \mathrm{Ga}$ ), has been given at Figure 1 and it has 8 atoms in its primitive cell. Also, the X-ray diffraction pattern (XRD) illustrated in Figure 2. According to the graph, $2 \theta$ value of maximum peak for $\mathrm{Al}_{4} \mathrm{As}_{3} \mathrm{Co} 27.22^{0}$ and for $\mathrm{Ga}_{4} \mathrm{As}_{3} \mathrm{Co} 27.15^{0}$.
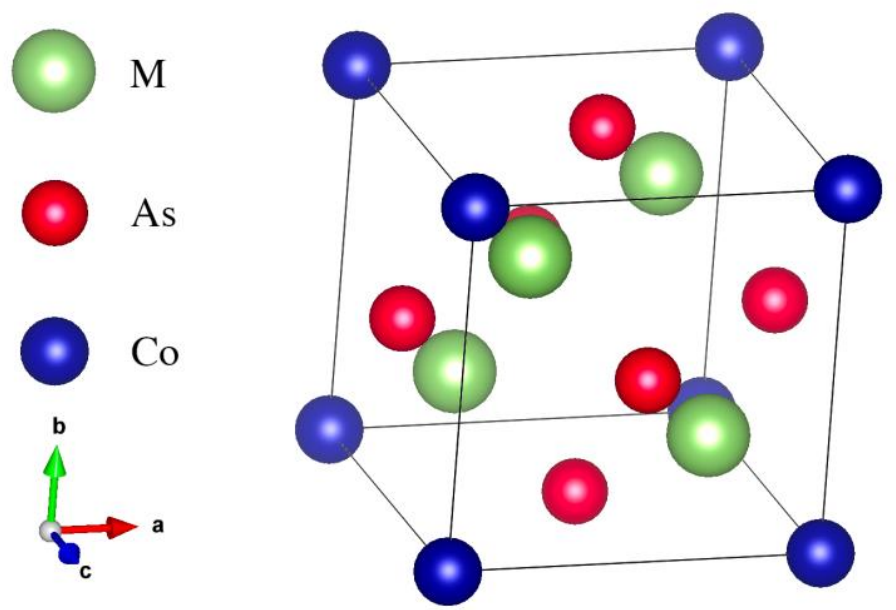

Figure 1. The primitive cell of $\mathrm{M}_{4} \mathrm{As}{ }_{3} \mathrm{Co}(\mathrm{M}: \mathrm{Al}, \mathrm{Ga})$. Green atoms represent aluminum and gallium, red and blue atoms represent arsenic and cobalt respectively.

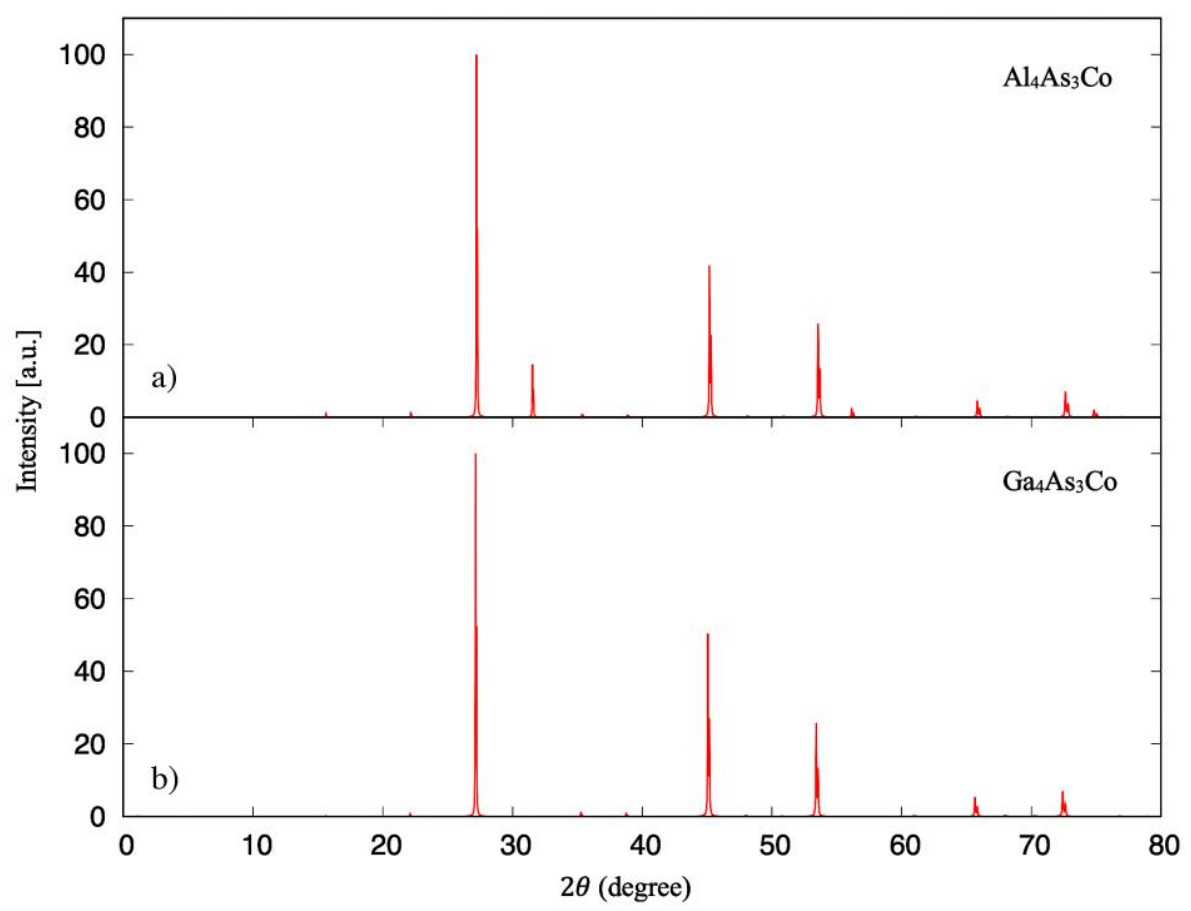

Figure 2. The X-ray diffraction (XRD) pattern a) $\mathrm{Al}_{4} \mathrm{As}_{3} \mathrm{Co}$ and b) $\mathrm{Ga}_{4} \mathrm{As}_{3} \mathrm{Co}$. 
Although, ferromagnetic order has magnetization, the total magnetization of antiferromagnetic order is zero. It is known that there are three type of antiferromagnetic phases which are G-type, C-type and A-type [24]. In this study, in order to find most suitable magnetic order, ferromagnetic and three type of antiferromagnetic orders have been employed. The total energy as a function of volume in ferromagnetic and three types of antiferromagnetic order has been plotted by using Vinet equation and given in Figure 3 [25]. From the graph it could be said that ferromagnetic order is most suitable for both of our materials, despite all the ground state energies are close to each other and it is hard to distinguish them. Also, all the antiferromagnetic phases have same energies with each other.
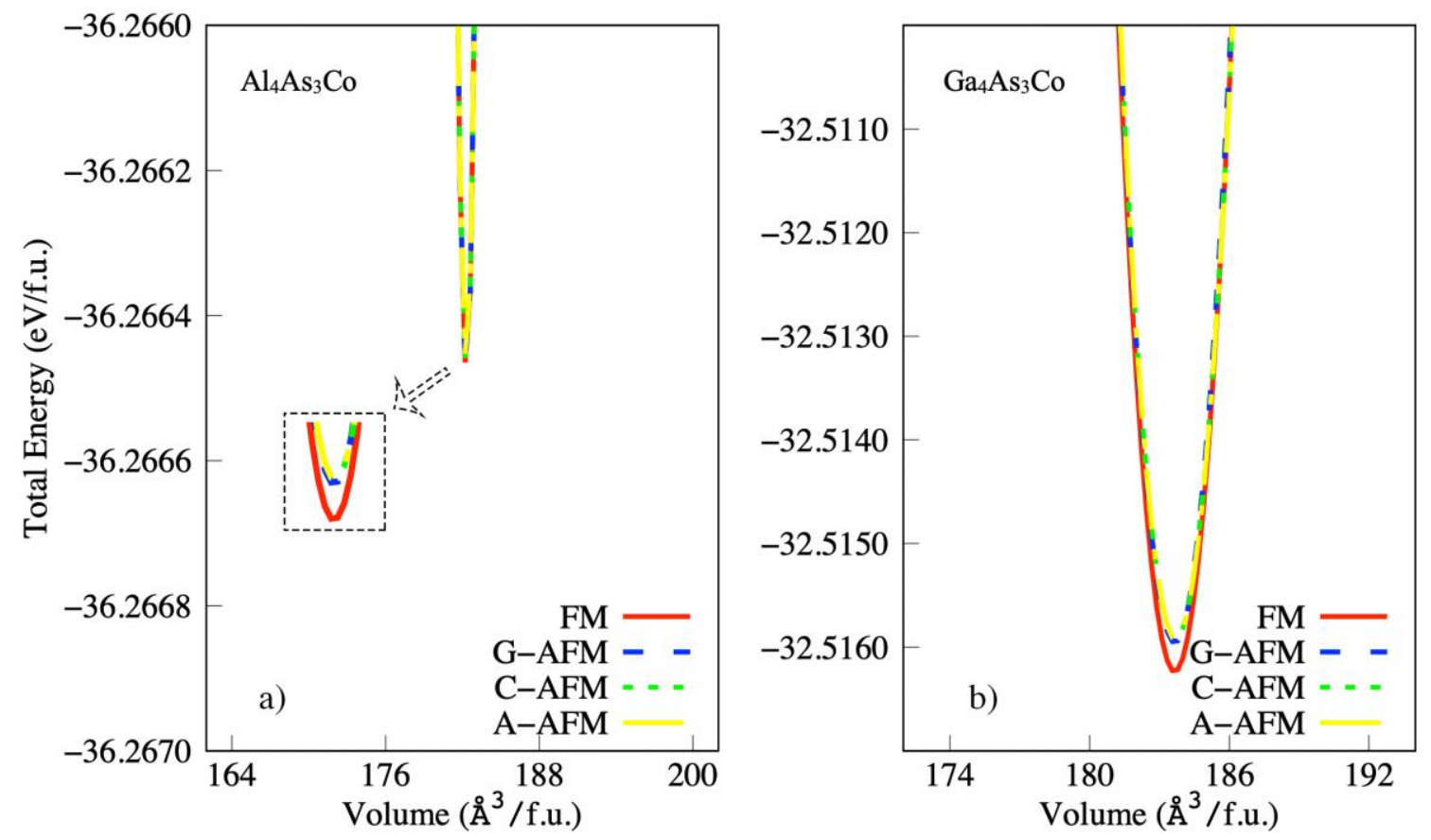

Figure 3. The total energy as a function of volume in ferromagnetic and three types of antiferromagnetic order (G, C and A type); a) $\mathrm{Al}_{4} \mathrm{As}_{3} \mathrm{Co}$ and b) $\mathrm{Ga}_{4} \mathrm{As}_{3} \mathrm{Co}$.

The formation energies $\left(\Delta E_{f}\right)$ have been calculated by using Equation 1 by employing total energy and ground energy of individual atoms [26].

$$
\Delta E_{f}=E_{M_{4} A s_{3} C o}-\left(4 E_{M}^{\text {bulk }}+3 E_{A s}^{b u l k}+E_{C o}^{b u l k}\right)
$$

Where $E_{M_{3} A s_{3} C o}$ is total energy, $\mathrm{M}$ is $\mathrm{Al}$ or $\mathrm{Ga}$ atoms, and the other energies are ground state energy of individual atoms. Alongside the formation energies the lattice parameters and bond lengths are given in Table 1. It can be said from the table, lattice parameters and bond lengths are greater for $\mathrm{Ga}_{4} \mathrm{As}_{3} \mathrm{Co}$. The calculated formation energies of both materials are negative, that means both compounds are energetically stable and structurally synthesizable. Also, for both compounds, most stable magnetic order is ferromagnetic phase, since the formation energy is lowest value. These results are compatible with energy-volume plots in Figure 3. 
Table 1. The optimized lattice parameters, bond lengths, and the formation energies of $\mathrm{M}_{4} \mathrm{As}_{3} \mathrm{Co}$ ( $\mathrm{M}$ : $\mathrm{Al}$,

\begin{tabular}{|c|c|c|c|c|}
\hline & & & a). & \\
\hline Compounds & $\mathrm{a}(\AA)$ & $\mathrm{d}_{\mathrm{M}-\mathrm{As}}(\AA)$ & $\mathrm{d}_{\mathrm{M}-\mathrm{Co}}(\AA)$ & $\Delta E_{f}(e V / f . u)$. \\
\hline \multirow{4}{*}{$\mathrm{Al}_{4} \mathrm{As}_{3} \mathrm{Co}$} & \multirow{4}{*}{5.67002} & \multirow{4}{*}{2.47564} & \multirow{4}{*}{2.39575} & $-1.8904(\mathrm{FM})$ \\
\hline & & & & -1.8904 (G-Type AFM) \\
\hline & & & & -1.8904 (С-Type AFM) \\
\hline & & & & -1.8904 (A-Type AFM) \\
\hline \multirow{4}{*}{$\mathrm{Ga}_{4} \mathrm{As}_{3} \mathrm{Co}$} & \multirow{4}{*}{5.68419} & \multirow{4}{*}{2.48935} & \multirow{4}{*}{2.38073} & $-1.0101(\mathrm{FM})$ \\
\hline & & & & -1.0098 (G-Type AFM) \\
\hline & & & & -1.0098 (C-Type AFM) \\
\hline & & & & -1.0098 (A-Tyре AFM) \\
\hline
\end{tabular}

\subsection{The Observed Electronic Band Structure and Density of States for $\mathrm{M}_{4} \mathrm{As}_{3} \mathrm{Co}$ (M: $A l, G a)$}

The electronic behavior of any compounds can be understood from electronic band structure with partial and total density of states. For our materials in this study, the electronic band structure and density of states, for spin up and spin down case, have been given in Figure 4. The band structures have been plotted along the high symmetry directions and generalized gradient approximation have been employed for both spin states. It is clearly seen from the figure that $\mathrm{Al}_{4} \mathrm{As}_{3} \mathrm{Co}$ compound has semiconductor nature with very little direct band gap $0.044 \mathrm{eV}$. On the other hand, $\mathrm{Ga}_{4} \mathrm{As}{ }_{3} \mathrm{Co}$ compound has zero indirect band gap for spin down and spin up cases.

The partial and total orbital projected density of states for each atom in the compounds have been plotted in Figure 5. For both of our compounds, greatest contribution to density of states comes from cobalt (Co) atoms. Especially, starting from $-1.5 \mathrm{eV}$ up to the Fermi energy level, 3d orbitals of Co atoms have dominancy. The significant difference between the $\mathrm{Al}_{4} \mathrm{As}_{3} \mathrm{Co}$ and $\mathrm{Ga}_{4} \mathrm{As}_{3} \mathrm{Co}$ is between -0.5 and $-3.0 \mathrm{eV}$-orbitals of gallium (Ga) atoms have strong hybridizations with p-orbitals of arsenic (As), this effect cannot be seen on Al.

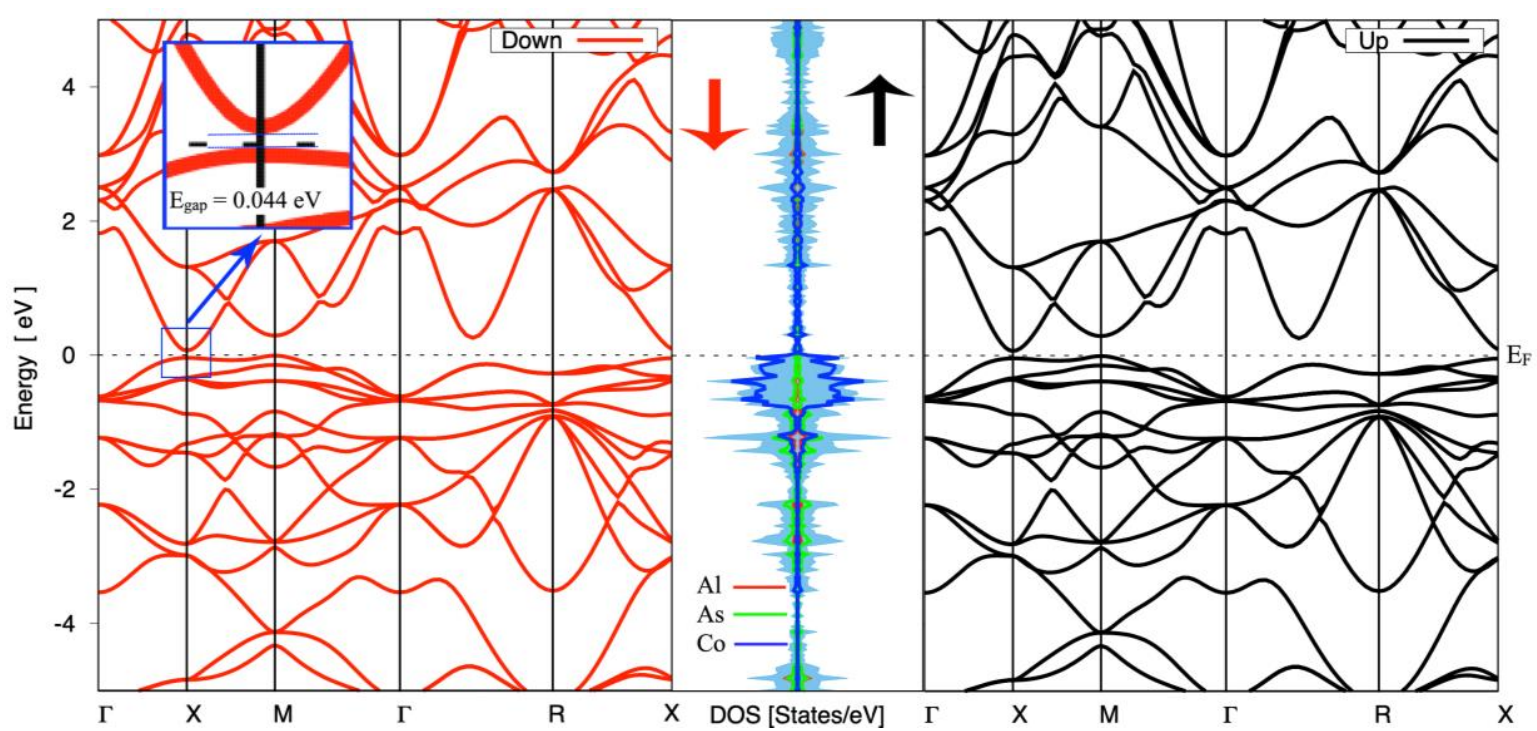

Figure 4a. Electronic band structure with total density of states for $\mathrm{Al}_{4} \mathrm{As}_{3} \mathrm{Co}$ compound. 


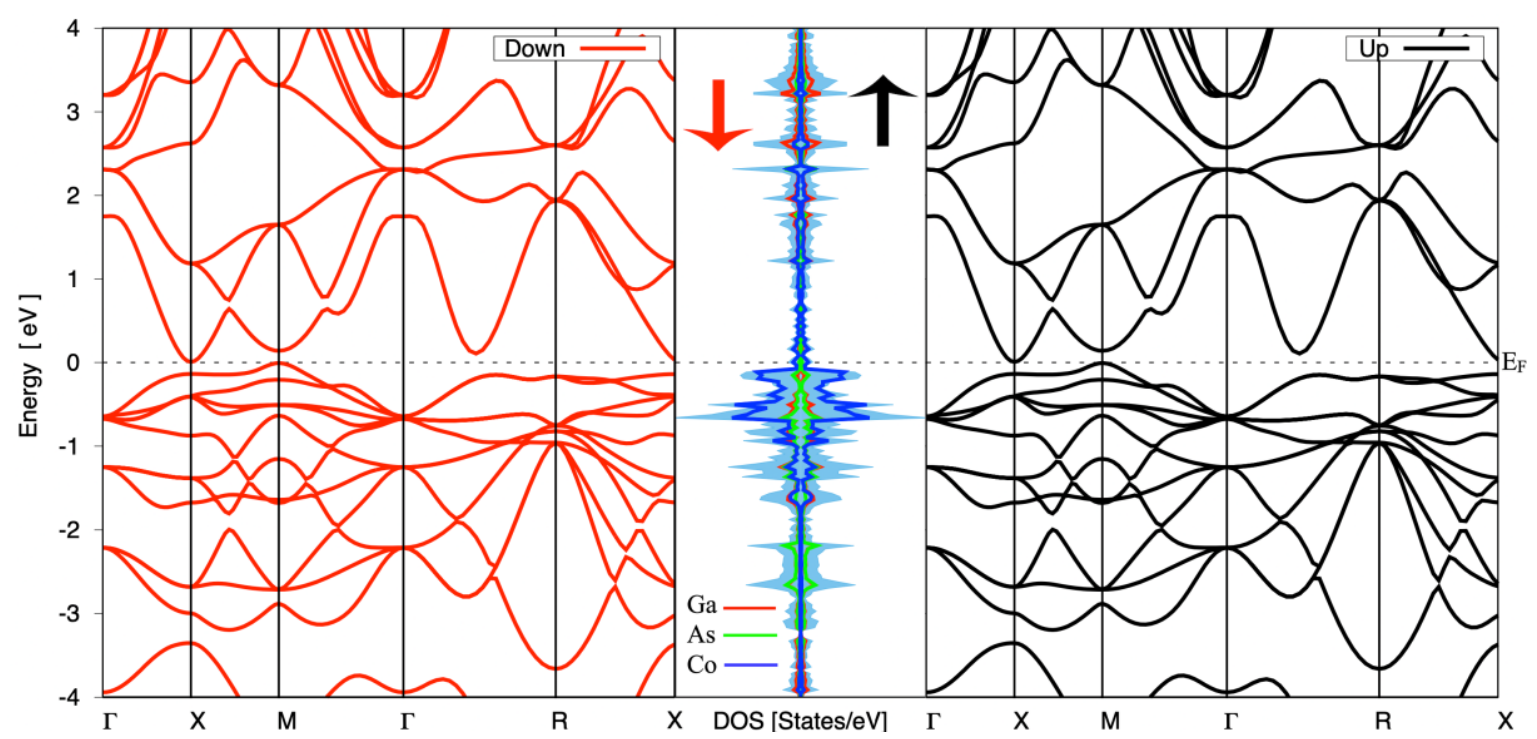

Figure 4b. Electronic band structure with total density of states for $\mathrm{Ga}_{4} \mathrm{As}_{3} \mathrm{Co}$ compound.

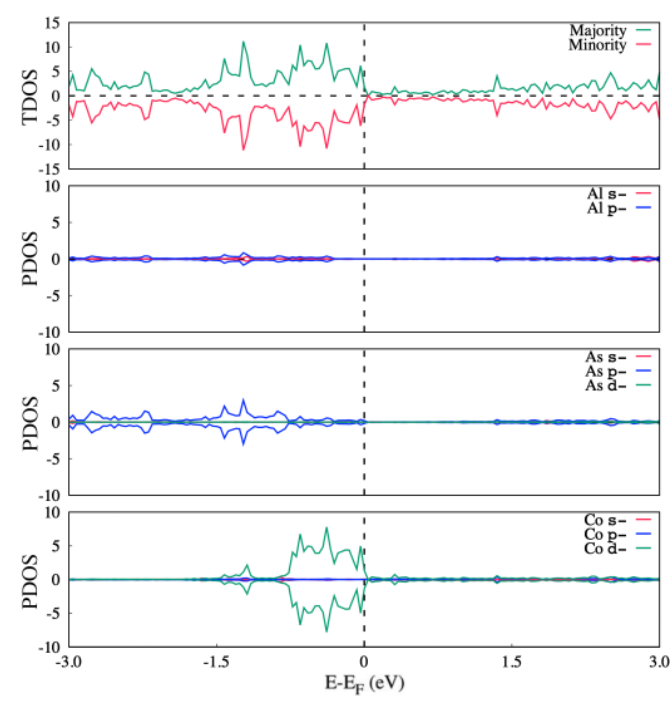

a)

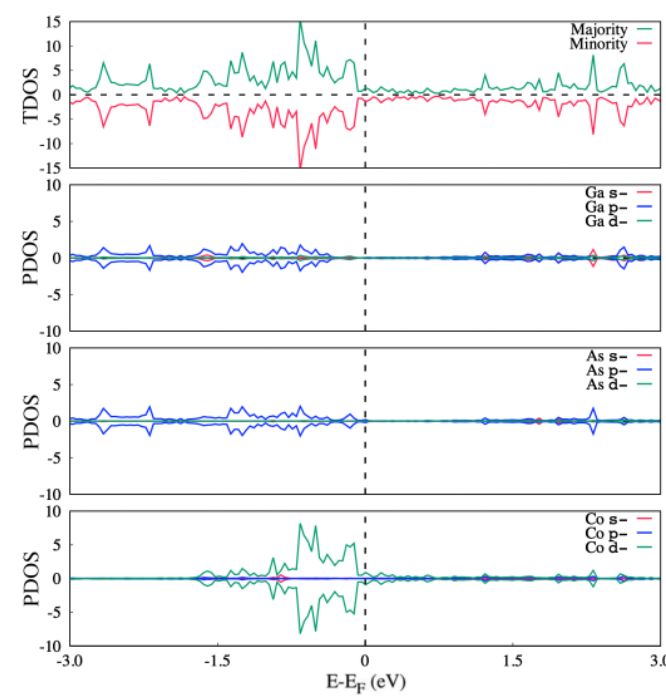

b)

Figure 5. Orbital projected partial (PDOS) and total density of states (TDOS) for a) $\mathrm{Al}_{4} \mathrm{As}_{3} \mathrm{Co}$ and b) $\mathrm{Ga}_{4} \mathrm{As}_{3} \mathrm{Co}$.

\subsection{The Calculated Elastic Constants and Predicted Mechanical Properties of $\mathrm{M}_{4} \mathrm{As}{ }_{3} \mathrm{Co}$ (M: $\mathrm{Al}, \mathrm{Ga}$ )}

In order to calculate elastic constants with first principal calculation, stress-strain approximation has been employed [27]. $C_{11}, C_{12}$ and $C_{44}$ three independents elastic constants are given in Table 2 for our compounds $\mathrm{M}_{4} \mathrm{As}_{3} \mathrm{Co}(\mathrm{M}$ : Al, Ga) [28]. In order to find out mechanical stability Born-Huang criteria, which are given as $\mathrm{C}_{11}>0, \mathrm{C}_{44}>0$, $\mathrm{C}_{11}-\mathrm{C}_{12}>0$ and $\mathrm{C}_{11}+2 \mathrm{C}_{12}>0$ have been tested. It is clearly seen that our elastic constants on Table 2 meet these criteria. 
Table 2. The determined elastic constants $C_{11}, C_{12}$ and $C_{44}$ in $\mathrm{GPa}$ for $\mathrm{Al}_{4} \mathrm{As}_{3} \mathrm{Co}$ and $\mathrm{Ga}_{4} \mathrm{As}_{3} \mathrm{Co}$ compounds.

\begin{tabular}{|l|lll|}
\hline Materials & $C_{11}(\mathrm{GPa})$ & $C_{12}(\mathrm{GPa})$ & $C_{44}(\mathrm{GPa})$ \\
\hline $\mathrm{Al}_{4} \mathrm{As}_{3} \mathrm{Co}$ & 86.2 & 50.5 & 35.0 \\
\hline $\mathrm{Ga}_{4} \mathrm{As}_{3} \mathrm{Co}$ & 90.8 & 50.2 & 25.5 \\
\hline
\end{tabular}

Furthermore, Young's $(E)$, bulk $(B)$, shear $(G)$ modulus and Pugh's $(B / G)$, Poisson's $(v)$ ratios are estimated from elastic constants. For the upper limit Voigt [29] and for the lower limit Reuss [30] approximations have been used in Eq.2-4.

$$
\begin{gathered}
B=\frac{C_{11}+2 C_{12}}{3} \\
G_{V}=\frac{C_{11}-C_{12}+3 C_{44}}{5} \\
G_{R}=\frac{5\left(C_{11}-C_{12}\right) C_{44}}{4 C_{44}+3 C_{11}-3 C_{12}}
\end{gathered}
$$

Also, the average value of shear moduli could be calculated by average value Hill [31] approximations, $\left(G_{v}+G_{R}\right) / 2$. Poisson's ratio $(v)$ and Young's moduli $(E)$ could be estimated from Eq.5 and Eq.6 respectively [32].

$$
\begin{gathered}
E=\frac{9 B G}{3 B+G} \\
v=\frac{3 B-2 G}{6 B+2 G}
\end{gathered}
$$

Table 3. The predicted shear $(G)$, bulk $(B)$ and Young's $(E)$ modulus in GPa, Pugh's $(B / G)$, Poisson's $(\sigma)$ ratios for $\mathrm{Al}_{4} \mathrm{As}_{3} \mathrm{Co}$ and $\mathrm{Ga}_{4} \mathrm{As}_{3} \mathrm{Co}$ compounds.

\begin{tabular}{|l|ccccccc|}
\hline Materials & $G_{v}(G P a)$ & $G_{R}(G P a)$ & $G(G P a)$ & $B(G P a)$ & $E(G P a)$ & $B / G$ & $v$ \\
\hline $\mathrm{Al}_{4} \mathrm{As}_{3} \mathrm{Co}$ & 28.14 & 25.28 & 26.71 & 62.43 & 70.12 & 2.345 & 0.3133 \\
\hline $\mathrm{Ga}_{4} \mathrm{As}_{3} \mathrm{Co}$ & 23.44 & 23.15 & 23.30 & 66.73 & 62.30 & 2.745 & 0.3371 \\
\hline
\end{tabular}

Incompressibility or compressibility could be understood from Poisson ratio ( v) [33]. If the value of Poisson ratio approach to the 0.5 compound shows incompressible character. For our case, each value is around 0.3. Therefore, our compounds have compressible nature. Also, the compressibility of the compound with $\mathrm{Al}$ is greater. Among the estimated mechanical parameters, for our first compound with $\mathrm{Al}$ has greater shear $(\mathrm{G})$ and Young $(\mathrm{E})$ modules than the compound with $\mathrm{Ga}$, but it has smaller bulk (B) modules. The ductility or brittleness can be estimated from Pugh's ratio. If $\mathrm{B} / \mathrm{G}$ value greater than critical value 1.75 , materials can be counted as ductile. As one can deduct from the Table 3, our both materials are regarded as ductile. 
However, the ductility of $\mathrm{Ga}_{4} \mathrm{As}_{3} \mathrm{Co}$ is greater than $\mathrm{Al}_{4} \mathrm{As}_{3} \mathrm{Co}$. Two-dimensional Young's modulus, linear compressibility, shear modulus and Poisson's ratio for $\mathrm{Al}_{4} \mathrm{As}_{3} \mathrm{Co}$ and $\mathrm{Ga}_{4} \mathrm{As}_{3} \mathrm{Co}$ given at Figure 6. It is also seen from the figure; linear compressibility is anisotropic for both compounds.

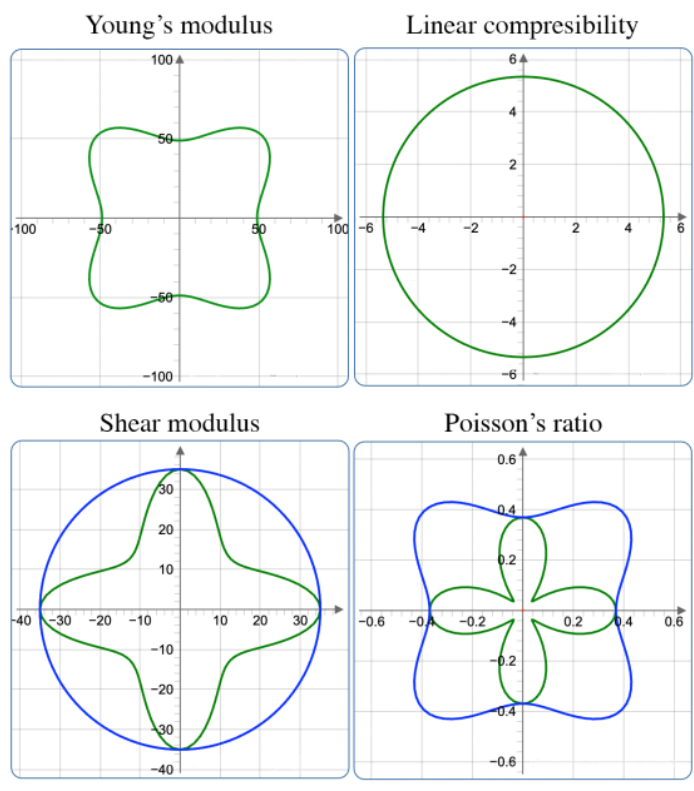

a)
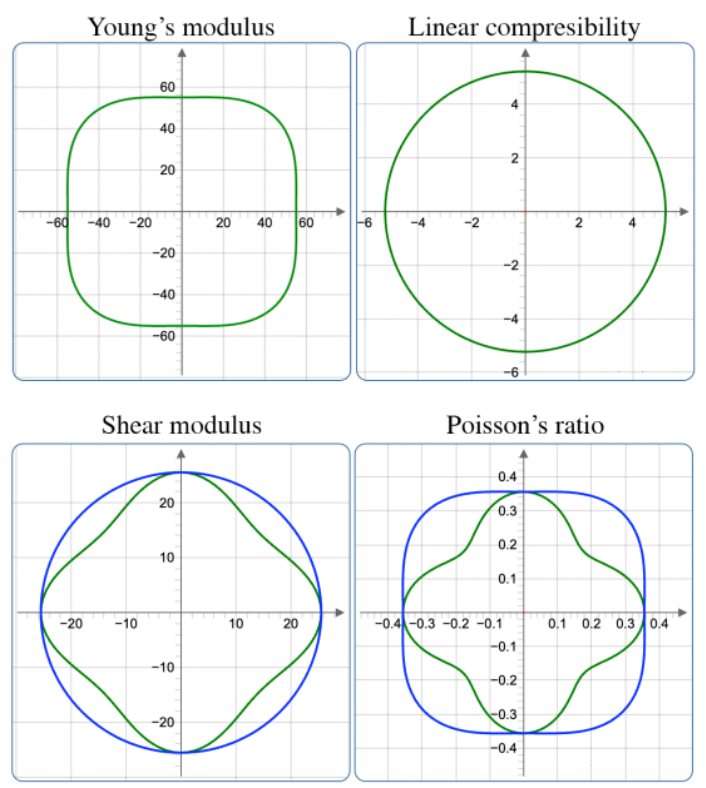

b)

Figure 6. Two-dimensional Young's modulus, linear compressibility, shear modulus and Poisson's ratio for a) $\mathrm{Al}_{4} \mathrm{As}_{3} \mathrm{Co}$ and b) $\mathrm{Ga}_{4} \mathrm{As}_{3} \mathrm{Co}$.

The last parameters that we are going to introduce, are wave velocities and Debye temperature. Wave velocities obtained from Navier's equation [34]. Debye temperature is significant parameter to understand the thermal behavior of compounds. Also, melting temperature and Debye temperature can be related. As one can deduct from the Table 4 Debye temperature and wave velocities are greater for $\mathrm{Al}_{4} \mathrm{As}_{3} \mathrm{Co}$ compound.

Table 4. The transverse $\left(v_{t}\right)$, longitudinal $\left(v_{l}\right.$ and average $\left(v_{m}\right)$ wave velocities and Debye temperature $\left(\Theta_{D}\right)$ for $\mathrm{Al}_{4} \mathrm{As}_{3} \mathrm{Co}$ and $\mathrm{Ga}_{4} \mathrm{As}_{3} \mathrm{Co}$ compounds.

\begin{tabular}{|l|llll|}
\hline Materials & $v_{t}(\mathrm{~m} / \mathrm{s})$ & $v_{l}(\mathrm{~m} / \mathrm{s})$ & $v_{m}(\mathrm{~m} / \mathrm{s})$ & $\Theta_{D}(\mathrm{~K})$ \\
\hline $\mathrm{Al}_{4} \mathrm{As}_{3} \mathrm{Co}$ & 3285 & 5654 & 3645 & 382.7 \\
\hline $\mathrm{Ga}_{4} \mathrm{As}_{3} \mathrm{Co}$ & 2825 & 4817 & 3132 & 328.0 \\
\hline
\end{tabular}

\section{Conclusion}

In this study, electronic and mechanical properties of $\mathrm{Al}_{4} \mathrm{As}_{3} \mathrm{Co}$ and $\mathrm{Ga}_{4} \mathrm{As}_{3} \mathrm{Co}$ compounds have been investigated in detail. $\mathrm{M}_{4} \mathrm{As}_{3} \mathrm{Co}(\mathrm{M}$ : $\mathrm{Al}, \mathrm{Ga}$ ) compounds have simple cubic structure conforming F-43m space group with 216 space number. Although all the ground state energies for both of our materials are close to each other, it is understood that, energetically most stable magnetic order is ferromagnetic order. The electronic band structures and density of states prove that, $\mathrm{Al}_{4} \mathrm{Ass}_{3} \mathrm{Co}$ compound has semiconductor nature with very little direct band gap $0.044 \mathrm{eV}$ and $\mathrm{Ga}_{4} \mathrm{As}_{3} \mathrm{Co}$ compound has zero indirect band gap. Our elastic constants on meet Born stability 
criteria. The estimated Pugh's ratios show that our materials have ductile nature. With semi-conductor and zero-gap band structure, our materials can be good candidate for spintronic applications or photovoltaic compounds.

\section{Author Statement}

Buğra Y1ldız: Investigation, Original Draft Writing.

Aytaç Erkişi: Investigation, Validation, Review and Editing.

\section{Acknowledgment}

This research was supported by the Pamukkale University Research Project Unit [project number 2019BSP013].

\section{Conflict of Interest}

As the authors of this study, we declare that we do not have any conflict of interest statement.

\section{Ethics Committee Approval and Informed Consent}

As the authors of this study, we declare that we do not have any ethics committee approval and/or informed consent statement.

\section{References}

[1] S. Mahajan (Ed.), Handbook of Semiconductors. Second ed., Elsevier, Amsterdam, 1994.

[2] S. J. Moss and A. Ledwith, The Chemistry of the Semiconductor Industry. Springer. ISBN 978-0216-92005-7, 1987.

[3] P. Palacios, P. Wahnon, and C. Tablero, "Ab initio phonon dispersion calculations for $\mathrm{Ti}_{\mathrm{x}} \mathrm{Ga}_{\mathrm{n}} \mathrm{As}_{\mathrm{m}}$ and $\mathrm{Ti}_{\mathrm{x}} \mathrm{Ga}_{\mathrm{n}} \mathrm{P}_{\mathrm{m}}$ compounds," Comput. Mater. Sci., 33, 118-124, 2005.

[4] P. Palacios, J. J. Fernandez, K. Sanchez, J. C. Conesa, and P. Wahnon, "First-principles investigation of isolated band formation in half-metallic $\mathrm{Ti}_{x} \mathrm{Ga}_{1-x} \mathrm{P}$," Phys. Rev. B, 73, 085206, 2006.

[5] A. Luque, and A. Martí, "Increasing the efficiency of ideal solar cells by photon induced transitions at intermediate levels," Phys. Rev. Lett., 78, 5014, 1997.

[6] P. Mahadevan and A. Zunger, "First-principles investigation of the assumptions underlying modelHamiltonian approaches to ferromagnetism of $3 \mathrm{~d}$ impurities in III-V semiconductors," Phys. Rev. B, 69, 115211, 2004.

[7] M. Wierzbowska, D. Sánchez-Portal, and S. Sanvito, "Different origins of the ferromagnetic order in (Ga,Mn)As and (Ga,Mn)N," Phys. Rev. B, 70, 235209, 2004.

[8] S. Sanvito, G. Theurich, and N. A. Hill, "Density functional calculations for III-V diluted ferromagnetic semiconductors: A review," J. Supercond. Novel Magn. Mater., 15, 85, 2002.

[9] K. Sato and H. Katayama-Yoshida, "First principles materials design for semiconductor spintronics," Semicond. Sci. Technol., 17, 367, 2002.

[10] L. Kronik, M. Jain, and J. R. Chelikowsky, "Electronic structure and spin polarization of MnxGa1-xN," Phys. Rev. B 66, 2002.

[11] T. Dietl, H. Ohno, and F. Matsukura, "Hole-mediated ferromagnetism in tetrahedrally coordinated semiconductors," Phys. Rev. B 63, 195205, 2001.

[12] H. Ohno, "Making nonmagnetic semiconductors ferromagnetic," Science, 281, 951, 1998.

[13] S. A. Wolf, A. Y. Chtchelkanova, and D. M. Treger, "Spintronics A retrospective and perspective," IBM Journal of Research and Development, 2006.

[14] S. Bhatti et al. "Spintronics based random access memory: A review," Materials Today, 20 (9), 530548, 2017.

[15] M. C. Payne, M. P. Teter, D. C. Allan, T. A. Arias, and J. D. Joannopoulos, "Iterative minimization techniques for ab initio total-energy calculations: molecular dynamics and conjugate gradients," Rev. Mod. Phys., 64, 1045, 1992.

[16] G. Kresse and J. Hafner, “Ab initio molecular dynamics for liquid metals,” Phys. Rev. B, 47, 558$561,1993$.

[17] G. Kresse and J. Furthmuller, "Efficiency of ab initio total energy calculations for metals and semiconductors using a plane-wave basis set," Comput. Mater. Sci., 6, 15-50, 1996.

[18] P. E. Blöchl, "Projector augmented-wave method," Phys. Rev. B, 50, 17953-17979, 1994. 
[19] W. Kohn and L. J. Sham, "Self-consistent equations including exchange and correlation effects," Phys. Rev. A, 140, A1133-A1138, 1965.

[20] P. Hohenberg and W. Kohn, "Inhomogeneous electron gas," Phys. Rev., 136, B864-B871, 1964.

[21] J.P. Perdew, K. Burke, and M. Ernzerhof, "Generalized gradient approximation made simple,” Phys. Rev. Lett., 77, 3865-3868, 1996.

[22] H. J. Monkhorst and J.D. Pack, "Special points for Brillouin-zone integrations," Phys. Rev. B, 13, 5188-5192, 1976.

[23] K. Momma and F. Izumi, "VESTA: a three-dimensional visualization system for electronic and structural analysis," Appl. Crystallogr., 41 (3), 653-658, 2008.

[24] F. Han, A Modern Course in the Quantum Theory of Solids. Singapore: World Scientific Publishing Co. Pte. Ltd., 2013, pp. 378-379.

[25] P. Vinet, J.H. Rose, J. Ferrante, and J.R. Smith, "Universal features of the equation of state of solids," J. Phys.: Condens. Matter., 1, 1941, 1969.

[26] C. Kaderoglu, G. Surucu, and A. Erkisi, "The investigation of electronic, elastic and vibrational properties of an interlanthanide perovskite: $\mathrm{PrYbO}_{3}$," J. Electronic Materials, 46, 5827-5836, 2017.

[27] Y. L. Page and P. Saxe, "Symmetry-general least-squares extraction of elastic coefficients from ab initio total energy calculations," Phys. Rev. B, 63, 174103, 2001.

[28] F. Mouhat and F. X. Coudert, "Necessary and sufficient elastic stability conditions in various crystal systems," Phys. Rev. B, 90, 224104, 2014.

[29] W. Voigt, Lehrbuch der Kristallphysik, B.G. Teubner, Leipzig und Berlin, 1928.

[30] A. Reuss, "Berechnung der fliessgrenze von mischkristallen auf grund der plastizitatsbedingung fur einkristalle," J. Appl. Math. Mech., 9, 49:58, 1929.

[31] R. Hill, “The elastic behavior of a crystalline aggregate," Proc. Phys. Soc. A, 65, 349-354, 1952.

[32] A. Erkisi, B. Yildiz, and G. Surucu, "First principles study on new half-metallic ferromagnetic ternary zinc-based sulfide and telluride $\left(\mathrm{Zn}_{3} \mathrm{VS}_{4}\right.$ and $\left.\mathrm{Zn}_{3} \mathrm{VTe}_{4}\right)$," Materials Research Express, 6, $076107,2019$.

[33] G. V. Sinko and N. A. Smirnov, "Ab initio calculations of elastic constants and thermodynamic properties of bcc, fcc, and hcp Al crystals under pressure," Journal of Physics: Condensed Matter., 14, 6989-7005, 2002.

[34] E. Schreiber, O. L. Anderson, and N. Soga, Elastic Constants and their Measurements. McGrawHill, New York, 1973. 